\title{
Rsearch on the Construction of Operating Mechanism of Characteristic Town Based on the PPP Financing Model
}

\author{
Qian Wang ${ }^{1, a}$, Shulian $\mathrm{Wu}^{1, \mathrm{~b},{ }^{*}}$ and Jiajia Zhu ${ }^{1, \mathrm{c}}$ \\ ${ }^{1}$ Department of Construction Management, School of Civil Engineering and Architecture, Zhejiang \\ Sci-Tech University, Hangzhou, Zhejiang, 310018 China \\ a1085889736@qq.com, bushulianwsl@126.com, ${ }^{\text {c } 876766607 @ q q . c o m ~}$ \\ * The corresponding author
}

\section{Keywords: PPP financing model; Characteristic town; Operating mechanism}

\begin{abstract}
As a national strategy, Characteristic Town has become an important carrier for promoting new-type urbanization and structural reforms on the supply side. However, the shortage of funds severely restricts the development of Characteristic Town. This paper discusses the introduction of the PPP financing model with strong financing attributes into Characteristic Town to effectively solve the financing problem. First, it analyzes the feasibility of introducing the PPP financing model from the perspective of the public department, the private sector, and the financial institutions. The operating mechanism of Characteristic Town PPP financing model was constructed from three aspects: organizational structure, operation flow, and profit model. Finally, some suggestions for ensuring the successful operation of the PPP financing model in Characteristic Town were put forward.
\end{abstract}

\section{Introduction}

In July 2016, the National Development and Reform Commission, the Ministry of Housing and Urban-Rural Development, and the Ministry of Finance jointly issued the "Notice on Developing the Cultivation of Characteristic Towns. " It has proposed that by the year of 2020, 1,000 unique towns of dynamic leisure and tourism, trade and logistics, modern manufacturing and education science and technology, traditional culture would be cultivated. It is simpled that Characteristic Towns' construction work started officially.

Characteristic Town is an important functional platform which is based on the development concept of innovation, coordination, green, open and share, to combine their own characteristics and identify industry orientation. [1]Because the fund demand of Characteristic Town project is large, try to let the PPP financing model apply to the Characteristic Town project. For the Characteristic Town PPP financing model, some domestic scholars mainly discuss it from three perspectives: feasibility, operation model and risk management. H. H. Su,et al. (2017) analyzed the feasibility and the necessity of the Characteristic Town PPP financing model. G. D. Ma,et al. (2017) discussed the feasibility from four aspects : policy orientation, participants' needs, operation foundation and practical experience. R. R. Wei,et al. (2017) analyzed the operation mechanism of the Characteristic Town PPP financing model. Y. Q. Xu,et al. (2017) identified and assessed the risks of Characteristic Town PPP financing model through questionnaire survey and grey correlation analysis to obtain the importance of risk rank. [2-5]

The above scholars' research has laid an important foundation for the Characteristic Town PPP financing model. However, there are still some deficiencies about the construction of the operating mechanism. The operating mechanism does not combine with financial instruments which is not helpful in guiding the actual work. This article attempts to use the financial tools to improve the operating mechanism of the Characteristic Town PPP financing model. 


\section{PPP Mode is a Feasible Way to Develop Characteristic Towns}

Government Sector Perspective. The characteristic town PPP financing model has been strongly supported by the government. Starting from 2016, the "Notice on Promoting the Construction of Policy-based Financial Support for Small Cities and Towns" and "Guiding Opinions on Accelerating the Construction of Small Towns with Beautiful Characteristics" all indicate the need to innovate the investment and financing mechanism for small (city) towns with distinctive features. And actively use the PPP financing model. Introducing the PPP model into the featured township project will relieve the government's debt pressure and reduce the government's fiscal expenditure. Secondly, it will make up for the government's expertise in financing, construction, and operations by borrowing the capital, technology, and management advantages of private capital. The lack of capacity guarantees the quality and efficiency of the featured township projects. The third is conducive to the transformation of government functions from builders to buyers and supervisors, and better reforms of policies, investment and financing, and other related institutional mechanisms.

Social Sector Perspective. The characteristic town is different from the ordinary single PPP project. It is a comprehensive PPP project integrating industry, culture, tourism and community functions, including land development, infrastructure construction, public service construction, and industrial development. The characteristic township PPP project with accurate positioning and reasonable operation not only expanded the investment opportunities of the social sector, but also improved the utilization rate and investment efficiency of the special town construction funds through the effective integration of social capital and financial funds, and it also helped the construction of characteristic towns. The formed industrial clustering advantage can better attract outstanding professional talents to develop their own business and expand brand influence. In addition, the social sector enjoys preferential policies in terms of land, taxation, funds, etc. at various stages of project construction, reducing its investment costs and ensuring a reasonable return on social capital.

Financial Institutions. Financial institutions include banks, insurance, trusts, and funds. The overall construction and operation of specialty towns need to rely on the financial integration of financial elements such as bank credit, insurance, funds, venture capital, and private equity financing to provide specialty town projects. The provision of funds and credit guarantees to overcome the shortcomings of the project itself with long investment cycles, large amounts of money, and slow recovery, so as to attract more social capital to participate in the investment and construction of featured towns. Financial institutions can also participate in investment as social capital. After the characteristic town is completed, the income can be realized through equity transfer. The Characteristic towns focus on industrial development and have a high probability of stable income during the operation period, which facilitates the recovery of debt funds. Besides, it also provides opportunities for creditors to realize business expansion.

\section{Operating Mechanism of Characteristic Town PPP Financing Model}

Organization Structure. The participants involved in the full life cycle of the characteristic town PPP financing model include: government departments, social departments, financial institutions, and other participants. The government department is usually the main sponsor of the project and is responsible for the work of planning, supporting the infrastructure, and ensuring the resource elements. [6] The social sector can be a corporation or a consortium composed of a number of corporations, mainly including private corporations, state-owned holding companies, joint-stock companies, and mixed-ownership enterprises. Cooperated with government agencies to set up a special purpose vehicle(SPV) as the main body for the implementation of characteristic town PPP projects, and is responsible for project financing, construction, operation and maintenance. Due to the huge investment in the early stage of the project, the proportion of equity investment in the private sector and government departments is usually small in the overall fund composition of the project. Most of the funds mainly come from financial institutions such as policy banks, commercial banks, trust and investment institutions. The following chart mainly disassembles the organizational 
structure of the characteristic town PPP financing model from the roles and mutual interests of participating parties:

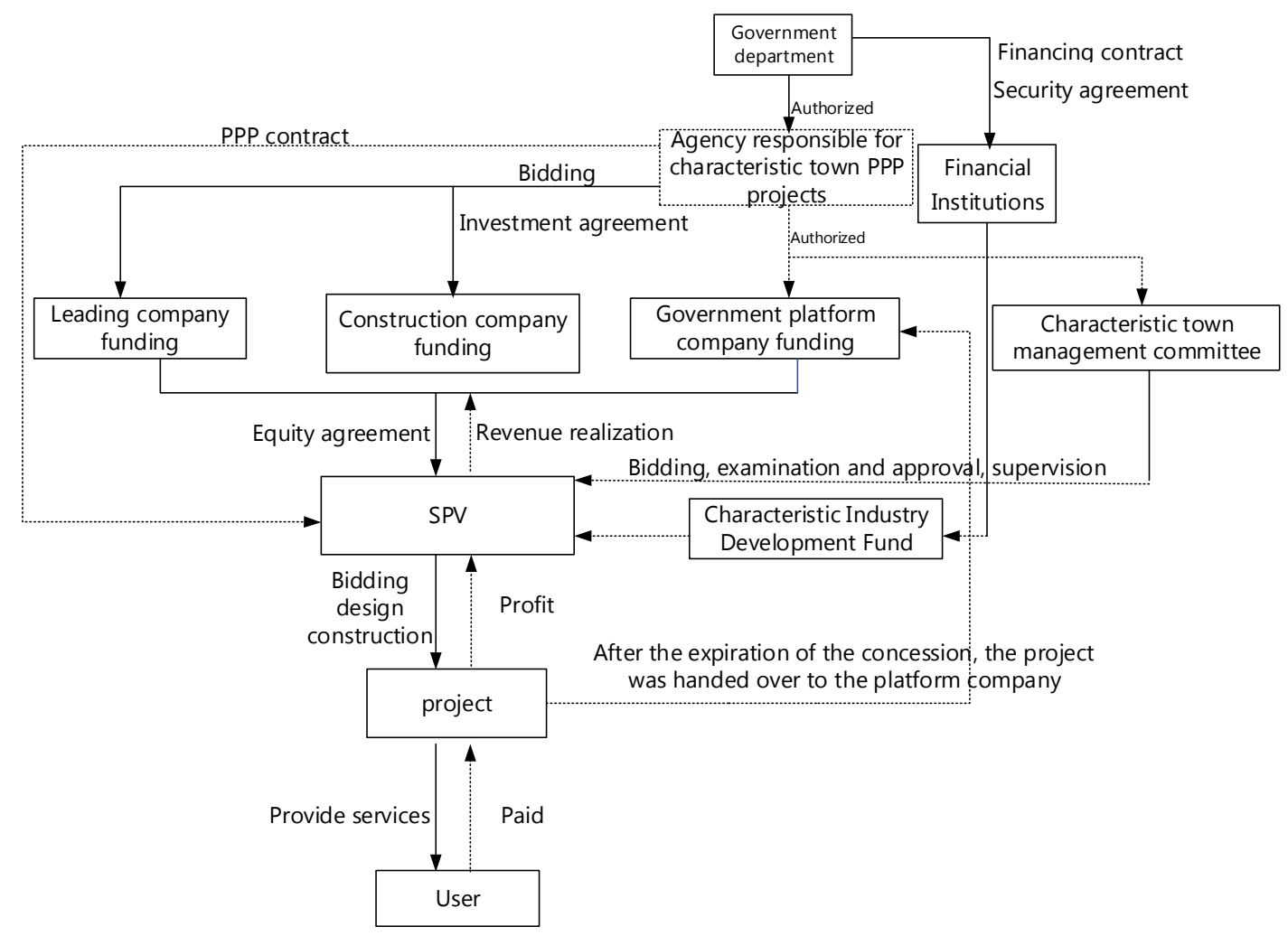

Figure 1. Finite Operation mode of PPP financing in characteristic towns

Operation Process. According to the government guideline, Characteristic Town PPP project follows the market operation. Its process is based on the PPP project operation process, combined with the relevant requirements of the Characteristic Town.

Project identification. Project identification includes four items: project initiation, project screening, value for money analysis, and government financial sustainability analysis. The purpose of project identification is to select some good Characteristic towns firstly, and then decide whether it could adopt the PPP model. The PPP model as a supplement to the traditional finance model, should be adopted carefully. Otherwise, the participants of the project would be in trouble.

Project preparation. At this stage, the local government shall accomplish the establishment of management framework and coordination mechanism between the agencies, and determine the project implementation agency. The project implementation agency shall prepare the project profiles, basic frameworks for risk allocation, and project operation methods, transaction structure, contract system, supervision structure, procurement methods.

Project procurement. The government generally chooses the private department through five ways: public bidding, invite public bidding, competitive negotiation, competitive negotiation and single-source procurement. Due to the comprehensiveness, particularity, and complexity of the Characteristic Town PPP project, it is recommended that competitive negotiation procurement could be adopted. At present, many estate developers participate in Characteristic Town PPP project. Select appropriate private capital become one of the goals in the prequalification process.

Project implementation. The project implementation agency and the financial department are responsible for supervising whether the social capital meet the requirements according to the procurement documents and project contract. At the same time, the two agencies will periodically monitor the project performance indicators. And the project implementation agency will conduct mid-term evaluation every 3-5 years in order to evaluate the risks of the identified problems and formulate countermeasures in time.

Project transfer. Project implementation agency formulate asset assessment and performance 
testing programs according to the transfer forms, compensation methods, transfer contents, and transfer standards agreed in the project contract. Project assets, intellectual property, and technical legal documents are handed over along with the list of assets. The financial department shall evaluate the performance of the PPP model application, project output, cost effectiveness, and regulatory effectiveness, and disclose the evaluation results after the transfer.

Profit Model. The profit model is an important basis for cooperation between the public department and private department. According to whether the project is profitable, there are three kind of projects: government-paid project, user-paid project, and feasiblity gap subsidy project. Based on the principle of "partnership, benefit-sharing, and risk-sharing", the distribution of benefits mainly considers the investment and the degree of risk assumed. In terms of social capital, the revenue from government-paid projects mainly comes from government subsidies; the main revenue from feasiblity gap subsidy projects or user-paid projects consists of two parts: "project operating income sharing + government subsidies". In terms of government, the main income is the revenue obtained from the transfer of land + tax, non-tax revenue + project special funds. These revenues are also the main source of funds for the government's cost and profit of each participant in the reimbursement project. [6] The income model of Characteristic Town project is a combination of real estate income + investment income + service income. And if the Characteristic Town project company is supported by an industrial fund, it can maximize its value through equity and IPO.

\section{Measures to Guarantee the Operation of Characteristic Town PPP Financing Model}

Risk Management. The risk of the Characteristic Town PPP financing model includes the conventional risk of the PPP project and the unique risk of the characteristic town project. The unique risks include the land acquisition risk, financial risk, government payment risk and industrial development risk. The core principle of risk management is to allocate risks to the party that has the most powerful control and the lowest cost. And it is a reasonable distribution of risks :the degree of risk assumed is matched with the rewards received.

Supervision Management. PPP project supervision includes contract management, administrative supervision and public supervision. In terms of contract management, due to the lack of competitive pressure on social capital, it is difficult for the government to supervise its performance effectively. Besides, when government agencies have poor performance, it is also difficult for social capital to take measures. In order to ensure that the public participate in the supervision work, the project implementation agency shall establish a publicity system for project work, and timely publish the process and results of the PPP project implementation plan, tendering, and negotiation through government websites and service halls.

Improve the Talent Itroduction Policy. The PPP model involves various fields such as engineering management, finance, law, and economy, and requires the cooperation of various professionals. At present, the PPP project in the Characteristic towns lacks corresponding professionals in overall planning, design, financing, construction, and operation. Faced with the problem of talent shortage, local governments can issue relevant talent introduction policies, provide preferential policies and subsidies for talents in terms of housing, income, etc. , and attract a group of composite talents. At the same time, government departments and project implementation agencies should also strengthen the training of personnel in the department to cope with the complex issues in the characteristic town PPP project. In addition, characteristic township enterprises can dock with universities to form a long-term stable cooperative relationship and increase the introduction of outstanding graduates.

Convert Government Role. Traditional government have diverse roles such as investment and finance, project construction, operation and maintenance. It lead to a result of high investment cost and low operation efficiency. Through adopting the PPP model can realize the transformation of government from builders to managers. At the same time, improve finance mechanism and government subsidy mechanism. In addition, some government departments should ensure clear responsibilities and achieve the efficient operation between them. 
Improve Laws and Regulations. The form of PPP legislation in China is based on the normative documents issued by central ministries and commissions. Last year, the validity of a guidelines issued by the Ministry of Finance in 2014 has expired. Therefore, the government legislature should base on the existing PPP normative documents, take all important factors within the whole life cycle of PPP project into consideration, and analyze the success and failure of the PPP model cases, find ways to solve PPP legislation issues as soon as possible.

\section{Acknowledgement}

This research was financially supported by Linan Zhengxin Engineering Consulting Co. , Ltd. . Research on Risk Assessment and Quantitative Sharing of PPP Project in Characteristic Towns $(17050425-\mathrm{J})$

\section{References}

[1] Y. Z. Wu, Q. H. Chen, X. H. Zheng: Planners, Vol. 32(2016) No. 7,p. 123. (In Chinese)

[2] H. H. Su, S. J. Wang: Project Management Technology,Vol. 15(2017)No. 6, p. 13. (In Chinese)

[3] G. D. Ma, T. H. Wang and S. Q. Zheng: Construction Economy, Vol. 38(2017) No. 8, p. 55. (In Chinese)

[4] R. R. Wei, X. Y. Zou: Tech-economics \& Management Research, (2017) No. 10,p. 125. (In Chinese)

[5] Y. Q. Xu,H. B. Yao,Q. An and H. Y. Zhao: Journal of Engineering Management,Vol. 31(2017)No. 6, p. 71. (In Chinese)

[6] F. Lin: China Real Estate, (2017)No. 5, p. 62. (In Chinese) 